\title{
WARTIME COLLABORATORS: A COMPARATIVE STUDY OF THE EFFECT OF THEIR TRIALS ON THE TREASON LAW OF GREAT BRITAIN, SWITZERLAND AND FRANCE.
}

Historically the concept of treason was evolved by legislatures and courts in order to protect the state from those domestic activities which threaten its destruction. Fear of the potential misapplication of the doctrine to the area of legitimate partisan conflict led to the enactment of legislation which specifies in precise terms the proscribed activities, establishes definite intent requirements, and provides special procedural and evidentiary safeguards for the trials of alleged traitors. The inadequacies of such traditional legislation to cope effectively with postwar demands of embittered populations for punishment of the huge number of wartime collaborators ${ }^{1}$ in Anglo-American and European countries have produced significant developments in the legal techniques utilized to safeguard national security and to punish violators thereof.

Prior to 1939 the major threat to national wartime security appeared to stem from the actual rendering of military assistance by citizens to the enemy; consequently pre-war European legislation was substantially focused on this single aspect of treason. However, such a delimitation of the concept failed to anticipate the emphasis by belligerents in World War II on the use of fifth columnists and psychological warfare; nor did it provide a defense against threats to industrial potential or to homefront morale. In addition, political tensions which developed as an incident to war combined in the postwar period to produce a climate of opinion within which the problem of punishment of wartime collaborators was raised from the level of legalistic "sect1rity" to the bitterly contested level of domestic politics.

The extent to which domestic treason laws were invoked to deal with col-

1. Reliable figures on the number of collaborators are still unavailable for many countries. In Denmark, immediately following the liberation, 22,000 suspected collaborators were apprehended. Givskov, The Danish Purge Trials (unpublished manuscript, 1946). In Norway, by the end of $1946,54,000$ out of the 75,000 persons accused of treason had been tried. Of these, 22,000 cases were dropped and 32,000 persons were found guilty. Politiken (Danish Liberal Daily), March 1, 1947. Estimates placed the number of Dutch collaborators at 18,000 , while in Belgium a government official stated that 60,000 collaborators had been arrested in the first year of liberation and that as of June, 1945, 16,959 cases had been tried. N. Y. Times, March 17, 1946, p. 19, col. 2 ; Vermeylen, The Ptmishment of Collabordtors, 247 AnNaLs 73, 75 (1946). Five hundred Swiss citizens were reported to have engaged in treasonous activities during the war, and in France, 125,000 collaboration cases were reported as of July, 1946. See note 103 infra. Seventy-five collaborators were tried in Great Britain and only about ten in the United States. Those tried in the United States were charged either with assistance rendered to German saboteurs or with having broadcast abroad in the service of the Axis governments. The outstanding treason trial in the United States concerned Anthony Cramer, a member of the first group. Sce Cramer v. United States, 325 U.S. 1 (1944). 
laborators differs among the various countries in accordance with the rigidity or flexibility of the national treason concepts and the intensity of popular demands. In general, the majority of the countries broadened their substantive treason provisions to interdict transmission abroad of industrial, economic and political information, and to prohibit activities which tended to wealen civilian support of the war effort. After the termination of war, ordinary criminal courts were frequently supplemented or superseded by the establishment of quasi-political courts ${ }^{2}$ or by military tribunals; ${ }^{3}$ substantive treason provisions were amended by specific legislation, ${ }^{4}$ or were broadened by judicial legislation $^{5}$ to modify earlier intent requirements and to include within their orbit political collaboration; and, finally, special laws were enacted to punish less serious offenders by administrative sanctions involving loss of civil rights, or loss of the right to engage in certain occupations or professions, or to hold certain types of public office. ${ }^{6}$

It is the purpose of this comment to analyze the treason laws and the collaboration trials conducted in pursuance thereto in Great Britain, Switzerland, and France, which have been selected as representative of the active Allied belligerents, the neutral powers, and the liberated countries of western Europe. The major developments in domestic treason laws will be explored, and the extent to which local collaboration problems were influential in this evolution will be indicated. Finally a preliminary effort will be made to evaluate the techniques employed to effectuate new governmental policies.

\section{Great Britain}

In comparison with France and Switzerland, the number of British subjects prosecuted in Great Britain for wartime activities regarded as inimical to national security was relatively small. This may in part be explained by the fact that Great Britain, although an active belligerent, was neither invaded nor occupied by enemy forces. Thus not only was her belligerent status a strong

2. This was the solution adopted by France. See notes $84-5$ infra, and by Denmarl;, see Givskov, op. cit. supra note 1.

3. Belgium utilized her regular military courts but changed their composition to include two civil magistrates, Vermeylen, supra note 1, at 75. In Holland special courts were created composed of three civilian barristers and two military advisers. News Digest (England) Dec. 21, 1944, No. 1640, p. 20. Note also the extensions of the jurisdietion of military courts to civilians charged with treason in Great Britain and Switzerland, notes 26 and 51 infra.

4. Although France and Switzerland had amended their treason laws prior to the outbreak of the war, The Netherlands, Denmark, Belgium and Sweden were forced to amend their laws retroactively after war had broken out.

5. See, for example, the decision of the English court in the trial of William Joyce, notes 29 and 31 infra.

6. See French decree on national indignity, note 67 infra. The Norwegian law is summarized in News Digest (England) May 16, 1945, No. 1760, p. 18. For Dutch provisions, see Id., Feb. 17, 1945, No. 1704, p. 3S. Belgian provisions are reported by Vermeylen, stpra note 1 , at 77 . 
unifying factor, but, in addition, the freedom of her citizens from contact with the enemy as reinforced by British trading with the enemy legislation reduced the possibilities and temptations of wide-scale assistance to the enemy.

As of April, 1946, British authorities had apprehended 125 alleged collaborators, 50 of whom were subsequently released without trial. ${ }^{7}$ These persons were chiefly British civilians who had been resident abroad during the war and British servicemen who had been taken prisoner by the enemy. The collaborationist activities with which they were charged involved the divulgence of military information to the enemy and.participation in the enemy propaganda service. To defend itself against this group, Great Britain invoked both its treason law and, for less serious offenses, its Defense of the Realm Regulations.

British Treason Law. The first British treason statute, enacted in 1351, classified the crime of treason into three types of activities: plotting the King's death, levying war against the-King, and adhering to the King's enemies by giving them aid and comfort. The statute provided a mandatory penalty of death upon conviction. With the development of the national state and the proportional diminution of the sovereign's power, the crime of treason was interpreted as applicable to acts endangering the security of the state as well as the person of the King. ' The first two sections of the basic statute were said to encompass acts endangering the internal security of the body politic, ${ }^{10}$ and it was therefore the third section which was generally invoked against wartime traitors. ${ }^{11}$

The act of adherence to the King's enemies had been judicially determined to embrace any act committed at home or abroad ${ }^{12}$ which was intentionally designed to render direct military assistance to the enemy. ${ }^{13}$ It included there-

7. The Times (London), April 12, 1946, p. 8, col. 4. With the exception of the trial of William Joyce, the complete reports of the proceedings against these collaborators are not available. Summaries of the charges and findings of the courts are contained in Roberts, Trial of William Joyce 172 et seq. (1946).

8. 25 Edw. III Stat. 5 c. 2.

9. This development received judicial recognition in Rex v. Maclane, 26 How. St. Tr. 722 (1797).

10. These sections were invoked extensively during the turbulent Stuart period. With the stabilization of the English political regime they fell into relative disusc. For an excellent analysis of the treason trials which occurred under these sections prior to 1790, see Brief for United States on reargument, pp. 55-170, Cramer v. United States, 325 U.S. 1 (1944).

11. This branch of the statute had not been utilized to any great extent prior to the 19th century. 2 Stephen, History of Crimtnal LaW of England 282 (1883); see also 8 HoldSWORTH, History OF ENGLISH LAw 307 (5th ed. 1937).

12. The statute of 1351 was first interpreted to apply to acts of treason committed abroad in Rex v. Casement [1917] 1 K.B. 98.

13. Rex v. Casement, stupra note 12 (incitement of Irish prisoners of war to join the Irish Brigade sponsored by Germany and participation in a "warlike and hostile expedition to Ireland with intent to invade Great Britain.") ; Rex v. Ahlers [1915] 1 K.B. 616 (assisting German subjects of military age to return to Germany; acquitted on other 
fore enlistment in the enemy forces, incitement of British soldiers to desertion, and the furnishing of military information to the enemy. ${ }^{24}$ It was considered immaterial for the purposes of conviction whether the aid sought to be rendered was in fact of any assistance to the enemy. In contrast to both Swiss ${ }^{15}$ and French ${ }^{16}$ law, British treason law by 1939 had not expressly been adjudicated as embracing activities directed primarily towards the weakening of the resistance power of the civilian population. ${ }^{17}$

The treason act of 1351 has been consistently interpreted to require proof of both intent and an overt act as prerequisites to conviction. ${ }^{18}$ The principle underlying these requirements, as emphasized by the British jurists in the 16th and 17 th centuries, was a desire to limit the broad field of treason and to prevent its extension to acts which did not in fact involve a breach of faith or a violation of allegiance to the King. ${ }^{10}$ Although these jurists were primarily concerned with the potential abuse of the first two sections of the treason act as a weapon against general political activity, British courts have consistently applied the same strict intent and overt act requirements to the crime of ad-

grounds); Rex v. Lynch [1903] 1 K.B. 444 (talking oath of allegiance to Orange Free State during Boer War, incitement of Irish prisoners of war to assist the enemy; commanding an Irish division with intent to cooperate with the Boer army); Rex v. Gregs, 14 How. St. Tr. 1371 (1708) (sending letter of intelligence to enemy); Trial of Capt. Vaughan, 13 How. St. Tr. 486 (1696) (cruising in French warship with intent to capture English ships while France and England were at war); Trial of Sir Richard Grahme, 12 How. St. Tr. 645 (1691) (boarding a ship destined for France allegedly carrying p3pers containing a plan for the invasion of England).

Various statutes passed from time to time explicitly defining acts prohibited under this branch of the statute bear out the concept of the statute as prohibiting acts of an essentially military nature. $3 \mathrm{Wm}$. and Mary c. 13 (1691) (prohibiting as treason the sending of arms, powder, bullets and other war materials to France); 9 Will. III, c. 1 (1697) (prohibiting as treason any correspondence with the late King James and his adherents); and compare the Treachery Act, 1940, $3 \& 4$ Geo. VI, c. 21, which provides that "if with the intent to help the enemy, any person does, or attempts ... to do, any act which is designed or likely to give assistance to the naval, military or air operations of the enemy, to impede such operations of His Miajesty's forces ... he shall be guilty of [treason]...."

14. Rex v. Casement, [1917] 1 K.B. 98; Rex v. Gregs, sstpra note 13; Trial of Capt. Vaughan, supra note 13.

15. See note 44 infra.

16. See note 70 infra.

17. However, frequent dicta in British treason cases indicate that the statute was regarded as embracing any act intended to weaken the power of the British population to resist or to attack the enemy. See Rex v. Casement, [1917] 1 K.B. 98; Rex v. Lymeh, [1903] 1 K.B. 444.

18. However, these overt act requirements were modified in cases involving plots against the life of the King. For such an indictment, proof of the conspiracy alone was often sufficient even without further evidence of overt acts. See Brief for United States on reargument, pp. 159 et seq., Cramer v. United States, 325 U.S. 1 (1944).

19. Cokf, Institutes of Laws of England, Thind Pabs 2-3, 21-2 (1644); 1 Hale, History of Pleas of the Crown 86 (Emlyn ed. 1736). 
herence to the 'King's enemies. ${ }^{20}$ Trials were conducted before the ordinary criminal courts, but in view of the serious nature of the crime, it was required that defendants be supplied before trial with a list of the jurors and that two witnesses testify to the overt acts charged in the indictment. ${ }^{21}$ This special procedure was abandoned in 1800 for the crime of compassing the King's death $^{22}$ and in 1940 for all trials involving the rendering of military assistance to the enemy. ${ }^{23}$ Finally, in 1945 , after the apprehension of William Joyce in Germany, Parliament assimilated procedurally all treason trials to those of ordinary felonies. ${ }^{24}$

The use of military courts for the trial of treason had been confined historically in England to cases involving members of the armed forces. ${ }^{25}$ However, under the Treachery Act of 1940 their jurisdiction was extended to embrace treasonous activities of alien enemies if committed within the United Kingdom..$^{26}$

British Action Against Collaborators. Of the 75 British subjects charged with wartime assistance to the enemy, seven were indicted for high treason, and the balance were prosecuted for offenses against the Defense Regulations. Under these regulations, ${ }^{2 \pi}$ " . . . any persons who with intent to assist the enemy committed an act which was likely to assist the enemy or to prejudice the public safety, the defense of the realm, or the efficient prosecution of the war ..." were subject to a maximum penalty of penal servitude for life.

20. For a modern case in which the court refused to infer a treasonable intent, sec Rex v. Ahlers [1915] 1 K.B. 616. In that case, the court acquitted the defendant who, while acting under a misapprehension of his duty as German consul in Liverpool, had assisted German citizens of military age to return to Germany after the outbreak of the war.

21. 7 \& 8 Will. III, c. 3 (1695).

22. $39 \& 40 \mathrm{Geo}$. III, c. 93 (1800). According to this statute, attempts on the life of the King were to be tried in the same manner as ordinary felonies.

23. The Act provided that all persons rendering direct assistance to the military operations of the enemy, impeding operations of the British forces, or committing acts of sabotage which endangered life, could be tried for treachery rather than for treason under the Act of 1351. Indictments for treachery were to be determined in the same manner as ordinary criminal indictments. In this manner the special procedures required for treason indictments were circumvented. Treachery Act, 1940, $3 \& 4$ Geo. VI, c. 21. See note 26 infra.

24. Treason Bill, 1945, 8 \& 9 Geo. VI, c. 44. For explanation of the legislative intent see 411 H.L. DEB. 1394-8 (5th ser. 1945).

25. The Naval Discipline Act, 1922, $12 \& 13 \mathrm{Geo}$. V, c. 37; The Army and Air Force (Annual) Act, 1929, 19 Geo. V, c. 20; The Air Force Act, 1930, 17 Halsbury's ConpLETE Statutes of England 306 (Butterworth ed. 1930).

26. Treachery Act, 1940, 3 \& 4 Geo. VI, c. 21. Three reasons were advanced for passing this statute: to enable the trial of enemy aliens who may not have established residence in Great Britain; to avoid the procedural requirements attached to treason trials by criminal courts; and to permit the joinder of treason charges with lesser offenses. 361 H.C. DEB. 185-229 (5th ser. 1940). The phrase "endangering life" was included to assure the possibility of including acts of sabotage within the crime of treason if so desired. Ibid.

27. Defense (General) Regulations, S.R. \& O., 1939, No. 927, §2A. 
The precise factors which determined the treasonous character of the acts engaged in are not clear, but appear to include the intent and motives of the actor, the sufficiency of the available evidence and the degree of assistance rendered the enemy. ${ }^{28}$

Three of the seven defendants indicted for treason had engaged in propaganda activities on behalf of the German Government through the medium of the radio and the political pamphlet. In the trial of William Joyce, the sufficiency of broadcasting for the enemy as an act of adherence was presented to British courts for the first time. Unfortunately, at the trial this issue was completely overshadowed in the arguments of counsel by the jurisdictional question of whether a non-resident alien holding a British passport could commit treason abroad. ${ }^{29}$ Defense counsel, in his summation, attempted to limit the treason potential of broadcasting in terms of the nature of the information broadcast. 30 The jury's verdict of guilty, however, appears in effect a finding that the mere act of broadcasting over an enemy network constitutes an act of adherence to the King's enemies, even though the falsity of the propaganda is clearly evident to listeners. ${ }^{31}$ Subsequent trials in Great Britain indicate that the treasonous nature of propaganda activities on behalf of the enemy is not dependent either on the financial reward to the defendant or on the medium of dissemination. ${ }^{32}$

As has been noted above, British treason law required that the Crown prove the existence of an intent on the part of the accused to assist the enemy. In the case of Joyce, the question of intent was not argued by the parties and the court in its instructions to the jury stated that the jury must determine for it-

28. See note 9 supra. See also remarks of British Attorney General with regard to the evidentiary difficulties in prosecuting the collaborators for high treason. 363 H.C. DEB. 41, 1246 (5th ser. 1940); 365 id. 1236.

29. The sole evidence introduced by the Crown consisted of the testimony of a British police inspector that he had heard Joyce broadcast that Dover and Folkestone had been totally destroyed by air raids, and of a workbook issued by the Germans in which the fact of Joyce's employment by the German Propaganda Service was recorded. HAus, Trtal of Wrustare JoYce 65 et seq. (1946). The legal effect of this testimony was only touched upon in the summations of the prosecution and defense. Id. at $209 \mathrm{ct} \mathrm{scq}$.

30. Id. at 209.

31. Id. at 223.

32. Walter Purdy was convicted of treason (subsequently reprieved) for having made records for German broadcasts, prepared pamphlets for distribution as enemy propaganda and served in an SS corps. The Times (London) Dec. 19, 1945, p. 2, col. 2. Thomas Haller Cooper, convicted of treason (subsequently reprieved), had been charged with having fought in a Waffen SS division in Russia and with having subsequently returned to Germany and written two pamphlets at the request of the German Forcign Office for distribution to English prisoners of war. RoBerTs, op. cit. supra note 7, at 182. John Amery, whose confession resulted in his execution, had not been employed in any eapucity by the German government. His offense consisted in having made frequent speeches to prisoners of war and internees in Belgium and Holland urging the conclusion of a peace between Germany and England in order to enable these countries to unite in opposition to the advance of Communism in Europe. Id. at $\mathbf{1 7 5}$. 
self whether the purpose of Joyce's broadcasts in English was to assist the Germans or the English, implying that the necessary intent can be inferred from acts of the accused. ${ }^{33}$ And, in the trial of William Purdy, ${ }^{34}$ the court, while reaffirming the necessity of establishing criminal intent, stated that, inas" much as a man must be presumed to have intended the consequences of his act, the burden was on the accused to prove that he had a different intention. ${ }^{36}$ It would appear, therefore, that in the treason trials of 1945-6 British courts have substantially modified the common law doctrine of intent.

\section{SWITZERLAND}

Surrounded on three sides by opposing belligerents, populated by French, Italian and German speaking groups, many of whom were domiciled aliens or political refugees, dependent on the external world for raw materials, and faced with a continuous propaganda barrage from all belligerents, Switzerland was confronted with serious threats to its neutrality and independence. Prominent in sowing the seeds of disunity were the German alien groups and the'Swiss Rightist parties, which espoused National Socialism and advocated close cooperation or even anschluss with the German Reich. ${ }^{36}$

As early as 1932, the Germans domiciled in Switzerland formed themselves into organizations patterned after those of the German Nazi party. ${ }^{37}$ They pub-

33. HALL, op. cit. supra note 29 , at 223 .

34. Purdy, charged among other things with broadcasting for the Germany Radio Service, defended on the ground that his purpose had been to win his freedom from the prisoner of war camp in which he had been confined and thus escape to Great Britain, and also to give weather information to the Royal Air Forces. The court apparently regarded the purpose of escape as a mere act of self-assistance and not sufficiently meritorious to justify the offense, but instructed the jury that a verdict of not guilty should be returned if Purdy had honestly intended to convey information to the R.A.F. The arguments of counsel and the instructions of the judge are fully summarized in Note, 10 J. CRIM. L. 182 (1946).

35. Purdy was sentenced to death but was granted a reprieve. The effect of this reprieve on the ruling of the court is not clear. If ordered by the Crown, no reason need be assigned. However, if granted by the trial court, it would indicate either the dissatisfaction of the judge with the verdict, the insufficiency of the indictment, or the existence of certain favorable circumstances in the defendant's character which convinced the court that time should be extended to him to apply to the Crown for an absolute or conditional pardon. See Wharton's Law Lexicon 870 (14th ed., 1938) ; Archbold, Plending, Evidence and Practice in Criminal Cases 204 (31st ed. 1943).

36. The material which follows on the organization and purposes of the German alien groups and extreme Rightist parties in Switzerland is based on Part 1 of a report recently issued by the Swiss Federal Council on anti-democratic activities in Switzerland during the war. Parts 2 and 3 dealt with Fascists and Communists. RAPPORT DU CoNSEIL FEDEral a L'Assemblé Federale Concernant L'Activité ANTt-Democratique exercte par Les Suisses et des Etrangers on Relation avec La Periode de Guekre 1939 A 1945 (Motion BoERLiN) Pt. I, Dec. 28, 1945; hereafter cited as RAppont.

37. These groups were arranged in a hierarchical organization with the N.S.D.A.P. Landesgruppe Schreiz at the top. Secondary units included youth clubs, sport and student groups, women's associations and the like. As of 1941 membership in these groups 
lished newspapers and disseminated propaganda material sent from Germany either by courier or through the German diplomatic pouch. WVorking in close association with these groups were extreme rightist Swiss political parties, some of which operated chiefly as propaganda organs, while others supplied the German government with general data on the local political, economic and military situation. After the outbreak of war, the extremist parties were dissolved, and many of their leaders fled to Germany to continue their propaganda activities. ${ }^{38}$

Swiss Treason Legislation. Although these activities were regarded as a grave threat to Swiss independence and neutrality, their essentially political nature caused considerable difficulty in the application of Swiss treason laws.

The Swiss treason law is contained in her penal and military criminal codes which, in common with continental systems of criminal law, are more precise and detailed and at the same time more extensive in scope than their British counterparts. The provisions of the Swiss treason law which relate to the external security of the country also differ from those of Great Britain in that they apply both in times of peace and war.

$U_{p}$ to 1942 , with the exception of certain amendments noted below, the applicable Swiss treason law was based on a penal code enacted in $1853.3^{\circ}$ In time of war it was considered high treason for any Swiss citizen to enlist in the enemy forces or intentionally to assist the activities of the enemy ; ${ }^{40}$ in time of peace, it was treasonous for a citizen to attempt to place any part of Switzerland under the control of a foreign power, to induce foreign powers to commit hostilities against Switzerland, or to interfere in her internal matters in a manner calculated to endanger her security. ${ }^{\prime 1}$ Finally, it was considered treasonable in time of peace for any Swiss citizen, in the course of an illegal act such as theft, to give intentional aid to the interests of a foreign state, and to the prejudice of Switzerland.2 With regard to internal security, the Swiss code of 1853 punished as high treason any participation in an act designed to change the federal constitution by force, forcibly to remove state officials designated by the constitution, or to deprive them of their au-

totalled 25,000. The total German and Austrian population in Switzerland was reported as 78,000 as of 1941 although it is not clear whether this figure included political refugees. The leaders of these groups took an oath of loyalty to Hitler and received their orders either from the German legation in Bern or directly from Berlin.

38. Those in Germany contributed frequent articles to the German press denouncing Switzerland for her unneutral attitude, attacking Swiss officials and the Swiss prople as "degenerate plutocratic Jewish Freemasons" and encouraging Swiss Nazis who remained at home to continue their efforts in behalf of National Socialism. Neue Zuercher Zeitung (Zurich), July 9, 1946, No. 1221, Col. 3. Mfany Swiss worked for German cceupation authorities. Le Figaro (Paris), April 23, 1945.

39. (1851-3) REcueIL OfFicred 3, 335; hereafter cited as C.P.S., 1853.

40. C.P.S., $1853, \S \S 36-7$.

41. C.P.S., $1853, \S 37$.

42. C.P.S.; $1853, \S 38$. 
thority. 43 In 1936, this code was broadened to inderdict attempts by noncitizens to place a portion of Swiss territory under foreign control, and to provide that any citizen or foreigner who committed an act tending to endanger the independence of the confederation should be guilty of treason.44

In 1942 the new Swiss penal code, which had been promulgated in 193\%, became effective. ${ }^{45}$ This code reproduced substantially the 1853 treason provisions as amended in 1936 and added certain new provisions under the heading of "diplomatic treason." By virtue of these additions, it became treasonable for any citizen or foreigner to reveal to a foreign government or to its agents or to the public any information which it was in the national interest to keep secret. ${ }^{46}$ Treason charges under this penal code are triable by ordinary criminal courts and the penalties which may be imposed vary from one to five years penal servitude. ${ }^{47}$

However, in Switzerland, unlike either Great Britain or France, civilians are also subject to the treason provisions of the military criminal code which differ in certain respects from those contained in the penal code. Thus under the Swiss military criminal code of $1927^{48}$ civilians found guilty of having obtained secret facts, processes, or articles for the purpose of making these available to a foreign government were guilty of treason.40 When a state of "active service" was proclaimed for Switzerland, civilians under this code were guilty of treason if they intentionally interfered directly or indirectly with the operations of the Swiss army, either by disrupting its means of communication, by disturbing public order or in any other manner. ${ }^{60}$ Under the military code, various acts of military espionage engaged in by military personnel were defined as treason, and by decrees of 1940 and 1942 , these provisions were extended to embrace similar activities of civilians. ${ }^{.1}$ Violations of the military code are punishable by Swiss military courts and the applicable penalties vary from three to five years penal servitude, ${ }^{52}$ except in time of war $^{53}$ or, since 1940, during a period of active service ${ }^{54}$ when the death penalty could be imposed.

Under both the penal and military codes, it is necessary to show that the

43. C.P.S., 1853, § 45 .

44. Federal Law of Oct. 8, 1936, (1936) 53 Recueir OfFicied 37.

45. (1938) 54 Recueit OfFicIEL 781; hereafter cited as C.P.S., 1937.

46. C.P.S., $1937 \S 267$.

47. C.P.S., $1937 \S \S 265-78$.

48. Federal Law of June 13, 1927, (1927) 43 RecueIt OfFictel 375; hereafter cited as C.P.M.

49. C.P.M. $\$ \S 2,86$.

50. C.P.M., $\$ \$ 3,87-91$.

51. Federal Council Decree, Aug. 29, 1939, (1939) 40 Recueil Officted 760; Ordinance, May 28, 1940, (1940) 56 Recuert Orficier 556; Federal Council Decree, Aug. 4, 1942, (1942) 58 RECUEIL OFFICIEL 743.

52. C.P.M. §§ 86-91.

53. C.P.M. $\S 27$.

54. Federal Council Decree, Aug. 4, 1942, (1942) 58 Recueir Orficiel 743, 86. 
accused intended to commit the acts defined in the treason provisions. No special procedural or evidentiary safeguards were established in treason trials. However, in $19 \pm 2$ certain procedural changes were made in order to enable treason proceedings to be conducted in camera if such a step appeared necessary to the court in the interest of national security. ${ }^{55}$ At that time it was also provided that Swiss criminal and military courts could order the preventive detention of persons whose activities appeared to endanger national security and the internment of those who had been convicted of crimes endangering national security. ${ }^{56}$

In addition to these judicial sanctions, certain administrative sanctions could be imposed on both Swiss citizens and foreigners whose conduct imported a threat to national security even in the absence of conviction for special offenses. These additional sanctions included the expulsion of foreigners either for life or for a stated period, ${ }^{57}$ and the annulment of the citizenship of both naturalized ${ }^{58}$ and native-born citizens ${ }^{50}$ who had engaged in "anti-national" activities outside the country. The latter power was enacted as an extraordinary war measure to be effective until $194 \mathrm{~J}$ and so far as is known was not renewed after that date.

Swiss Action Against Nasi Elements. Although the 1936 amendment to the penal code had been enacted with a view to providing a judicial sanction against the most serious pro-Nazi political activities in Switzerland, the provision was not invoked prior to the outbreak of the European war. ${ }^{60}$ Legis-

55. (1942) 58 RECUEIL OFFICIEL 743.

56. See note 51 supra.

57. Swiss Feperal Const. $\$ 70$, cited in Rao, Senect Co:istitutro:is Of tae WORLD 517 (1934).

58. (1941) 57 ReCUEIL OfFiciel 1289.

59. Emgenössissche Gestzsansarlung, No. 21, Bern, May 20, 1943. Reported instances where Swiss citizens were denationalized for undesirable activities abroad revesl the caution with which this decree was invoked. In two cases the parties affected held another nationality so that the withdrawal of Swiss nationality did not leave them stateless. Neue Zurcher Zeitung (Zurich), Dec. 10, 1945, No. 1876; Gazette de Lausanne, July 14, 1945, No. 176. The denationalization of Max Leo Keller, leader of the National Bearegung der Schweiz, one of the largest of the Swiss Rightist Parties, was announced only after his conviction in absentia for military treason. Nationsle Zeitung, June 14, 1945. Proof that the activity was willful and constituted an actual danger to Swiss neutrality was apparently insisted upon where no prior conviction had been secured. In the case of Georges Oltramare who had fled to France to work for the occupation authoritics, the Federal Council refused to act on a denaturalization request presented in 1943 on the ground that his actions at that time had not adversely affected Swiss neutrality. Journal de Geneve, Oct. 22, 1945, No. 249. Oltramare is now on trial for treason having been apprehended at the end of the war. Id., April 19-26, 1946, Nos. 92-7.

60. In the case of foreigners, proof of their intermeddling in Swiss affairs was deemed insufficient to warrant their prosecution for treason, and in the case of Swiss citizens mere espousal of Nazi doctrine was not considercd as a sufficient threat to the independence of the confederation within the meaning of the amended provision. Rarrosx $4,9,15,18,26$. 
lative and administrative measures were devised during the pre-war period to enable authorities to maintain a rigid supervision over the activities of both groups, ${ }^{61}$ and to control the types of propaganda disseminated.62

During the war, however, Swiss authorities made determined efforts to deal with approximately 500 Swiss and an indeterminate number of foreigners who engaged in treasonous activities. ${ }^{63}$ The majority of those who were indicted for treason were charged with endangering the military security of the country by the delivery of military information to foreign powers ${ }^{\text {os }}$ Death sentences were pronounced in several cases, against both Swiss citizens and foreigners. Since the termination of hostilities, popular demands for the punishment of those whose wartime activities were regarded as contrary to the national interest were directed primarily against alien Nazis and Fascists in Switzerland. Swiss purge measures instituted to meet this demand involved administrative rather than penal action and were designed to secure the expulsion of those foreigners whose continued presence in Switzerland was considered undesirable.

The only postwar treason trials involving treasonous political activities were conducted against Swiss citizens who had continued their propaganda on behalf of National Socialism after the dissolution of the rightist parties.05 Charged with the commission of acts tending ta endanger the independence of the confederation, these defendants have pleaded ignorance or lack of sympathy with the rightist program, lack of intent to threaten Swiss independence, and inability to disobey the orders of the group's leaders. Despite incomplete reports of the trials, it appears that these defenses have been con-

61. The basis for all federal action against alien groups in Switzerland was contained in the directives issued by the Federal Council in Sept. 1935. (1935) 2 FEunLL: FEderale 457. These directives, supplemented in 1936 by Federal Cauncil Decree, enabled Swiss authorities to control some political activities of these groups. (1936) 52 REcuEIL OFFICIEL 845.

62. Decree of Federal Council, Dec. 5, 1938, (1938) 54 RecueIL OfFreiel 880. Individual violation of decrees was promptly punished and where foreigners were involved, their expulsion was ordered.

63. Statement of Deputy in Bern State Council reported in St. Galler Tagblatt (St. Gallen), Sept. 6, 1945. In some instances trials in absentia were conducted against those Swiss who were operating from abroad. See report of trial by military court of Major Laurenz in 1941, Ia Suisse, Oct. 16, 1945, No. 289; also of Swiss citizen, A. Fuchs, reported in St. Galler Tagblatt (St. Gallen), June 30, 1945; Leonhard and Burri, leaders of the rightist party, Schweizerische Gesellschaft fur Attoritär Demokratic (SGAD) were tried in absentia for attempts against the safety of the Confederation and condemned to five years at hard labor. RAPPORT 61-2.

64. Reports of these trials appeared in the N. Y. Times. See, e.g., id., Fcb. 4, 1942, p. 4, col. 6; id., Feb. 22,.1942, p. 6, col. 2; id., May 3, 1942, p. 32, col. 4; id., Sept. 26, 1942, p. 4, col. 2; id., April 1, 1943, p. 6, col. 7; id., May 29, 1943, p. 3, col. 7. Sec also Neue Zurcher Zeitung (Zurich), May 5, 1943.

65. For reports of these trials, see Neue Zurcher Zeitung (Zurich), July 9, 1946, No. 12211, and Easler Nachrichten (Basel), March 20, 1946, No. 120; id., Aug. 19, 1946, No. 346; id., May 4/5, 1946, No. 184. 
sidered by the courts at least in mitigation of the sentences. The penalties imposed have varied from short term imprisonment to four-year sentences accompanied by temporary loss of civil rights or, in a proper case, by military degradation and expulsion from the army.

On the basis of the available material on the Swiss wartime experience, it is interesting to note that, although Switzerland was not involved in actual hostilities during World War II, many of the statutory changes in her procedural and substantive treason law closely parallel similar changes introduced into the treason law of Great Britain and the western European countries. In addition, in at least one respect Swiss law went further than its non-Axis neighbors by authorizing the denationalization of its citizens for offenses against national security. With respect to the penal trials, available evidence indicates an extreme caution on the part of Swiss authorities to invoke their treason law against those engaging in undesirable political activities. These trials, moreover, do not suggest any substantial modification of Swiss treason law with respect to the requirement of proof of treasonable intent.

France

The great number of French collaborators, estimated at about 125,000, was partiaily attributable to the German occupation of France which of necessity produced frequent contacts between the French citizenry and occupation authorities, and partially to the confusion of loyalties which existed among Frenchmen as a result of the armistice and the existence of rival governments in Vichy and London. The collaborators whose punishment was demanded included leading Vichy government officials and minor civil servants, as well as ordinary citizens who had in some manner contributed affirmative support to Vichy policies or had exhibited an anti-national attitude during the war.

Persons who were accused solely of anti-national conduct were dealt with by administrative purge commissions which had power to exclude them temporarily from public office or from their professions. ${ }^{60}$ On the other hand, persons who had rendered assistance to the enemy or prejudiced the unity of the nation or the freedom of the people, but whose activities did not fall within the scope of the penal laws, were prosecuted by tribunals (channbres civiques) attached to the purge courts for the offense of national indignity - a crime specially created by the government in August, 1944.07 These

66. Purge commissions were set up for: the administrative services of Metropolitan France, Ordinance of June 26, 1944, (1944) CoLLECTION COAspLETE nes LoIs, ET DÉGrets D'INTÉRÉTS GÉNÉRAL 356 (Sirey, N.S. 1944); architects, Ordinance of Sept. 13, 1945, Id. No. 19, 458; men of letters, authors and composers, Ordinance of May 30, 1945, Id. No. 12, 237; professional actors and musicians, Ordinance of Feb. 17, 1945, Id. No. 5, 99; for the press, Ordinance of March 2, 1945, Id. No. 6, 112; doctors, dentists and midwives, Ordinance of Jan. 18, 1945, Id. No. 3, 67; commerce and industr; Ordinance of Oct. 16, 1944, Id. 440; banks, Ordinance of Feb. 14, 1945, Id. No. 5, 96; hereafter cited as CoLLECTION COMPLETE.

67. Ordinance of Aug. 26, 1944, (1944) Courectrox Courpleste 385 as amended by Ordinance of Dec. 26, 1944, Id. No. 1-2, 18. 
civic tribunals were empowered to order the total confiscation of the property of the accused and could in addition permanently deprive defendants of all civil rights as well as of the right to exercise their professions or to hold certain official or corporate offices. The most serious offenders were indicted for treason under the penal laws in force in 1939. The complex nature of the problems which were encountered by the French Government in these trials may be attributable to the political disorganization within France after her liberation, to the large number of persons facing trial and to the difficulty of applying a French treason law geared to a situation of actual hostilities to acts committed during a subsequent armistice period.

French Treason Legislation. The French treason provisions, like the Swiss, are detailed and precise. Prior to $1939,{ }^{68}$ it was considered treason for a Frenchman to bear arms, or to intrigue with a foreign power to commit hostilities against his country. ${ }^{69}$ It was also treasonous for a Frenchman to intrigue with enemies of the state with intent to facilitate their entrance into French territory, to furnish them with assistance in soldiers, men, money, provisions, arms or ammunition, or to weaken the morale of French forces.70 Correspondence with enemy subjects was banned if it furnished information prejudicial to the military or political situation of France or her allies. ${ }^{71}$ Finally, any person having official knowledge of a diplomatic secret or expedition who betrayed it to a foreign power was deemed a traitor. ${ }^{72}$ Under these provisions, it is necessary to prove that the defendant intended to commit the act for the purposes defined in these provisions. An exception to this re. quirement was made with reference to the act of correspondence with enemy subjects. It was considered sufficient for conviction of this last offense to prove that the correspondence in fact resulted in the specified injury to the military or political situation in France. ${ }^{73}$

Barely two months before the outbreak of war in Europe, France revised and extended this legislation to bring it more in line with the dangers presented to national security as a result of modern warfare techniques. Undoubtedly influenced by the practice of various nations of omitting a formal declaration of war prior to attack, France abandoned the distinction in her old law between "enemy" and "foreign" powers and provided that henceforth to intrigue with any "foreign" power for the purposes specified in the earlier law

68. The French penal code provisions relating to treason prior to 1939 as well as the amendments introduced in that year can be found in Darloz, CODE PÉNAL $88 \mathrm{ct} s c q$. (1946); hereafter cited by article number; pre-1939 provisions will be indicated as C.P. $\$ 76$ (old), etc.

69. C.P. $\$ 76$ (old).

70. C.P. $\$ 77$ (old).

71. C.P. $\$ 78$ (old).

72. C.P. $\$ 80$ (old).

73. 3 Garraud, Droit Penal Français 521-36 (1916). 
was to be regarded as treason. ${ }^{74}$ Similarly the provision relating to enlistment in the enemy forces was amended to apply to enlistment in the forces of a foreign power and to the enrollment of such persons on behalf of a foreign power at war with France. ${ }^{75}$ The 1939 amendments provided further that it would be treason for any Frenchman or foreigner to reveal to a foreign power a secret of "national defense" which was defined generally as military, political, economic or industrial information. ${ }^{70}$ For the first time civilian sabotage of any instrument of war or any installation or equipment capable of utilization in the national defense was proscribed as a treasonous act. Similarly it was declared to be treason to participate knowingly in any move to demoralize either the army or the nation for the purpose of injuring the national defense. ${ }^{77}$ All convictions under these laws carried a penalty of death, although this was not mandatory.

After the liberation of France, some of the members of the Consultative Provisional Assembly urged that the substantive penal code provisions dealing with treason be amended so as to include certain activities which, although regarded by the people as criminal, did not fall within the scope of the penal laws. Their members feared that unless provision was made for the punishment of these activities, individual repression would be substituted for legal repression. Furthermore, it was argued that the prohibition against retroactive legislation, while applicable in normal times, should not be invoked if it would result in "outraging the national conscience by leaving unpunished unpardonable crimes against the country."78 However, the government was unwilling to enact a comprehensive collaboration law and passed instead certain "interpretive" provisions ${ }^{79}$ which although not formally retroactive would appear in fact to have such effect. It was provided, for example, that acts which were regarded as prejudicial to an Allied nation at war with the Axis powers were also to be regarded as an offense against France and punished accordingly. Similarly, acts committed against the Resistance forces and others who continued to fight after the armistice were to be punished in the same manner as offenses committed against regular French troops.

Under the French penal code, it is a complete defense to a major crime if the defendant acted pursuant to a law or to the orders of a legitimate authority. ${ }^{80}$ However, under the "interpretive" provisions this doctrine of superior

74. C.P. $\$ 77$. In addition, the amendments provided that in time of war, it would be treasonous to intrigue with a foreign power for the general purpose of "aiding its activities against France."

75. C.P. $\$ 76$.

76. C.P. $\$ \$ 76,78$.

77. C.P. $\$ 76$.

78. Report of M. Dumesnil de Gramont, Chairman of the Commission of Ieg. and Reform. Journal Officies, Débats, No. 57/58, 148-151 (1944).

79. Ordinance of June 26, 1944; (1944) Collection Costrlete 356.

80. C.P. $\$ 327$. 
orders was substantially modified. ${ }^{81}$ Any acts committed in obedience to the laws and decrees of the Vichy government by those Frenchmen who held leading administrative or executive positions or who by their own personal initiative could have avoided the execution of such laws or orders were specifically excepted from the superior order doctrine. Nor could the defense be invoked by those who had denounced persons to the enemy, committed individual acts of violence, or willfully delivered material, documents or information to the enemy. ${ }^{82}$

Procedure. Under the French constitutional laws of 1875,83 all treason indictments brought against high government officials were required to be tried by the Senate sitting as a High Court of Justice; where similar indictments were brought against ordinary citizens, the jurisdiction of the High Court of Justice was not mandatory and the government could in its discretion provide that the accused be tried by regular criminal courts.

Upon the liberation of North Africa in 1943, it was determined to utilize military courts for the trial of collaborators until the ordinary criminal courts could be reconstituted. However, in November, 1944, the government, yielding to demands for' a swifter mode of trial and for representation of the resistance elements in the courts, ${ }^{84}$ established a High Court of Justice to try all government officials attached to the Vichy government during the period from June $1 \%, 1940$ to the date of liberation,, 85 and special "courts of justice" to try all nongovernmental persons charged with violations of the Frencli penal code whenever there was evidence of an intent to aid any enemy undertaking. ${ }^{88}$ The jurisdiction of these courts was not restricted to violations of the treason provisions alone but extended to any unlawful act committed with intent to aid the enemy.

The High Court of Justice was composed of two judicial officers plus 24: jurors selected from two lists drawn up by the Provisional Consultative As-

81. It is interesting to note that in April, 1944, Great Britain made a similar modification of the doctrine of superior orders in regard to violations of the rules of varfare committed pursuant to an order. British Manual of Military Law $\llbracket 443$, cited in 60 L. Q. Rev. 225-6 (1944); note support of this modification in British parliamentary debates on war criminals, 130 H. L. DEB. 120, 130 (5th ser. 1943) ; 133 H. L. DED. 283-4 (5th ser. 1944).

82. Ordinance of June $26,1944, \S 3$, (1944) Collection Conplete 356.

83. Constitutional Law on the Relations of the Public Powers, July 16, 1875, §12, cited in RAO, op. cit. supra note 57, at 470; for discussion of this provision, see EsMeIN, ELEMENTS DE DROIT Constitutronner 1054-66 (1914).

84. These demands were vigorously urged in the early debates which took place in North Africa over the slowness with which the trials of Pucheu and other collaborators were proceeding. Opinion differed as to whether military tribunals were adequate or whether special courts should be created. At that time the De Gaulle government was opposed to the creation of special courts, Supplement au Journal Officter, Demats, No. 6, pp. 1-12 (Jan. 15, 1944), and No. 23, pp. 5-7 (March 16, 1944).

85. Ordinance of Nov. 28, 1944, (1944) Collectron COMPLETE 488.

86. Ordinance of Nov. $18,1944, I d$. at 481 . 
sembly, the first list to consist of 50 Senators or Deputies who had been in office September 1, 1939 and the second list of persons outside this category as selected by the Assembly. ${ }^{87}$ Special "courts of justice" were composed of a presiding officer selected from among the French judiciary and four jurors chosen by a commission composed of members of the French judiciary and the Departmental Committees of Liberation. ${ }^{88}$ The establishment of these courts was not regarded as an infringement of the principle of non-retronctivity which was deemed to be applicable only to substantive penal legislation. ${ }^{89}$ Nor would their quasi-political character appear to be at variance with the French concept of treason as essentially a political crime triable by a political body. 80

However, the government had regarded the composition of the special courts of justice as a temporary expedient necessitated by the conditions prevailing in France after her liberation. Accordingly in 1945, an amendment to the November decree was passed assimilating the procedure of juror selection for these courts to that utilized in the regular criminal courts although no change was made in the number of jurors selected. ${ }^{01}$ Charges of bias and prejudice on the part of the judges and jurors of the High Court of Justice 22 as well as the establishment in France of a regularly elected Senate and Assembly led to similar changes in the High Court as a result of which the presiding officials were elected by the Assembly and the jurors selected from a panel of 96 Deputies. $^{93}$

87. Ibid. $\$ 2$.

88. Ordinance of Nov. 28, 1944, §9, (1944) Coltectron Cossplete 488.

89. See statement of M. de Menthon, Jouratal Officize, Dég.iss, No. 57/58, 151 (July 21, 1944).

90. EsAren, loc. cit. stpra note 83 .

91. The membership of the commissions selecting the jurors for the courts of justice was changed to comprise representatives of the departmental general councils instead of the national liberation committees. Since the liberation committees were in many areas dissolved, and since, as a result of the elections, the general councils were functioning again in France, the change was felt to constitute a step in the gradual return of France to normalcy. A Communist proposal which would have required the consent of the liberation committees to the juror nominations was defeated 19-10 with two abstentions. Journal Offictei, Debats, No. 13, p. 220 (Dec. 14, 1945).

92. The conduct of the Laval trial, in which the accused was twice expelled from the court room for the uproar which he caused among the jurors and the judge, was described by the press as deplorable and was reported to have stimulated the government to revise the composition of the High Court. Le Monde (Paris), Oct. 6, 9, 11, 1945; N. Y. Times, Dec. 28, 1945, p. 9, col. 4. See also Jounnal Ofrictra, DÉnits, LTo. 13, pp. 218-21, (Dec. 13, 1945).

93. So reported in The Times (London), Dec. 29, 1945, p. 3; see also N. Y. Times, Dec. 28, 1945, p. 9, col. 4. In Aug., 1945, after the acquittal of Pierre Flandin, the Communist members of the jury resigned in protest against the ineffectiveness of the court. A Communist reform bill, proposing the abolition of all judicial representatives on the bench, and public instead of private deliberations and vote of the court, was rejected by a vote of 430-142. Le Monde (Paris), Aug. 10, 1946, p. 3; N. Y. Times, Aug. 9, 1946, p. 6, col. 3; P.M., Aug. 1, 1946, p. 7, col. 1. 
The procedure adopted by the High Court and the special courts of justice involves several substantial modifications of that ordinarily followed by French criminal courts. ${ }^{94}$ In the High Court of Justice, the functions of the juge d'instruction and the chambre d'accusation were performed by a single commission composed of five judicial officers nominated by the Minister of Justice and the Assembly and of six non-judicial representatives selected by the Assembly. ${ }^{95}$ No appeal was permitted from the decisions of the Commission. ${ }^{96}$ The trial procedure before the High Court was similar to that generally followed in criminal trials with the important exception that the new law provided that the judge and jury should deliberate together on the guilt of the defendant. ${ }^{97}$ No appeal as of right was granted. ${ }^{.8}$

In the special courts of justice, the proceedings before the chambre d'accusation were omitted entirely ${ }^{99}$ and although the right to appeal from the interlocutory judgment of the juge d'instruction was not abolished, only the chief prosecutor (procureur générale) was entitled to exercise it. ${ }^{100}$ At the trial the procedure followed was similar to the High Court with the same curious provision with respect. to the deliberations of the judge and jury.101 The accused was granted 24 hours in which to appeal from the final judgment of the court, but new trials were to be ordered only for errors of law which were regarded as prejudicial to the essential rights of the defense. ${ }^{102}$

Treason Trials. The French Minister of Justice announced that as of July 1,1946 , the French purge courts had considered 125,000 cases involving various acts of collaboration. ${ }^{103}$ Of this group well over 5,000 were charged

94. French criminal procedure is divided into three stages: a preliminary investigation of the evidence before a single magistrate known as the juge d'instruction (a proceeding without counterpart in Anglo-American procedure), an $c \cdot x$ partc examination of the indictment before the chambre d"accusation, which is a proceeding analogous to the Grand Jury, and finally the trial conducted before a single judge and twelve jurors. Appeals (appel) from the interlocutory judgments of the juge d'instruction may be taken by the government or the complaining witness (partie civile) and both the accused and the prosecution. may appeal (pouvoir en cassation) from the judgments of the chantbre d'accusation and of the court conducting the trial. In the latter cases, a successful appeal by the accused can only result in a new trial; in the case of an appeal by the prosecution from a judgment of acquittal, the disposition of the appeal has no effect on the judgment and is allowed solely to permit the correction of rulings of law which inight otherwise create unfortunate precedents. For a description and analysis of French criminal procedure, see LA VIE Juridique des PeUpLes, France, No. 3, 131-42 (Ullmann and Mirkine-Guetzévitch eds. 1933).

95. Ordinance of Nov. 18, 1944, Arts. 6-9, (1944) Colrection Conplete 481.

96. Id., Art. 9.

97. Id., Art. 10.

98. The accused, however, can petition for extensive clemency. Ibid.

99. Ordinance of Nov. 28, 1944, Tit. 3, (1944) Collection Conplete 488.

100. Ordinance of Nov. 18, 1944, Art. 17, (1944) Collection Complete 481.

101. Id., Art. 51.

102. Id., Art. 66 .

103. Statement of M. Teitgen, reported in Extinfor, PAGES of FrANCE, No. 1413 
solely with treason. The trials were conducted on the premise that a state of war continued to exist between Germany and France despite the armistice and that Germany therefore constituted an enemy power within the meaning of the treason statutes. ${ }^{104}$ The issues raised at the trials centered primarily on the amount of responsibility to be attached to individual defendants for the acts of their subordinates, on the extent to which the plea of superior orders would be permitted by way of defense, and finally on the degree to which the motives or intentions of the defendants would be weighed by the court in assessing guilt and sentence.

The trials of Vichy officials proceeded on a theory of treason which looked not solely to the act or intent of the defendant but rather to the effect of this act upon the national interests. In the trial of Marshal Petain, ${ }^{105}$ for example, the prosecution charged that the treason of the accused lay in his definitive acceptance of defeat, in the humiliation of France before the world by virtue of the institution of a Nazi-like regime, and finally in the loss of French honor which resulted from Petain's aid to the enemy. ${ }^{103}$ Petain contended that his actions were motivated solely by his desire to save French independence and thus contribute an indirect aid to the Allies, ${ }^{107}$ but the court ignored this claim and held that in fact Petain's policy resulted in direct aid to the Germans while its contribution to the Allied cause was at most of uncertain value. Of greater importance, the court pointed out, was the fact

(Publication of French Press and Information Service, New York, Sept., 1946). The purge courts established in France had jurisdiction over all acts which were committed with intent to assist the enemy even though these acts did not constitute treason. The overall figures given by M. Teitgen do not distinguish between those which involved treason and those which did not. MI. Teitgen stated that the number of death sentences imposed totalled 5,000 and that 29,000 cases involved penalties ranging from penal servitude for life to short term imprisonment. For this reason, the figure of $5,060 \mathrm{may}$ be said to represent the minimum of treason cases tried.

104. This issue was raised by the defense in the trial of Georges Suarez, see note 116 infra. Defense counsel maintained that France and Germany were not legally at war and that after the armistice, Germany was at most a foreign power within the meaning of the treason statutes. The court rejected the argument, and stated that a state of war existed and that the armistice constituted merely a suspension of hostilities. Le Figaro (Paris), Oct. 24, 1944, pp. 1-2.

105. The complete stenographic report of the Petain trial is contained in Mrcurer, Le Procìs Du Marḱchal Petan (Paris, 1946).

106. 2 MTCHEL, op. cit. sitpra note 105 , at $892-4$. This thesis was developad at considerable length by the prosecution, id. at 925 et scq. The prosecution made no efiort to represent Petain as "one who had for personal reasons sold his country to the enemy:" Id. at 892 .

107. Defense summation is quoted at 2 Mfrchen, op. cit. supra note 105 , at 955. Defense also claimed that Petain could not be held responsible for the policies of his ministers, over whom he had no control. The court denied the validity of this claim, pointing out that as Chief of State, Petain had assumed legal responsibility for their aets and that it was on his own initiative that many of these ministers had been appointed. 2 id. at 1117 . 
that the policy deceived not only the Allies, but also many Frenchmen who in good faith believed it was their duty to abandon the Allied cause and participate in the collaboration with Germany. Therefore, the court concluded, Petain was clearly guilty of "intelligence" with the enemy, although it exonerated him from the charge of having plotted against the internal security of the country.

This same concept of treason was applied in the trials of Admiral Esteva, ${ }^{108}$ Resident-general of Tunisia, and General Dentz, ${ }^{100}$ High Commissioner of the Levant States, the courts rejecting in both cases the defense that each had acted solely in pursuance of Vichy orders. The prosecution in the trial of Esteva maintained that "collaboration to the extent to which Esteva carried it or even the mere appearance of collaboration was a crime because it allowed the world to think that France was truly collaborating and to believe that all Frenchmen approved of such a policy."110 Esteva was found guilty of treason but received a life imprisonment sentence instead of death because of the assistance which he had rendered to French patriots and to American Consul Doolittle at the time of the German invasion. ${ }^{111}$ In the trial of General Dentz, ${ }^{112}$ the accused based his defense on a portrayal of the disastrous consequences which disobedience of Vichy orders would have entailed for French interests in the Middle East. - However the court held that this defense did not justify Dentz's actions in firing on Allied and Free French forces in Syria, and found him guilty of treason.

Subsequent trials of Vichy Ministers, ${ }^{113}$ however, indicate that the High

108. The indictment against Esteva is summarized in Le Monde (Paris), March 14, 1945, p. 2; in general the criminal acts on which the charges were based included his sending of food to Rommel's Afrika Korps in Lybia, recruitment of laborers for work in Germany, his failure to resist German demands in Tunisia, his agreement with tho Germans to place at their disposal all necessary facilities for their fight against the Allied invasion forces, and finally his failure to order resistance to the German landings in North Africa after the Allied invasion. The documentary evidence on which these charges were based is collected in part in Ministère de L'Information, Le Procds dc L'Admiral Estera, Notes, Documentaires Et Etudes, No. 33, March 10, 1946.

109. The indictments and proceedings of the trial of General Dentz were fully reported in Le Monde (Paris). For summary of the indictment see Le Monde (Paris), April 19, 1945, p. 2. Dentz was charged primarily with furnishing the enemy forces with military facilities in Syria and with firing on British and Free French forces in obedience to Vichy orders.

110. Le Monde (Paris), March 16, 1946, p. 2. At the time of the invasion of North Africa, the prosecution argued, the fatality of Petain's policy to French interests was obvious to all Frenchmen and none could in good faith have been deceived by it.

111. The decision of the court is summarized in Le Monde (Paris), March 17, 1945, p. 2.

112. For a report of the daily proceedings, see Le Monde (Paris), April 21, 1945, p. 3; id., April 22/23, 1945, p. 2. Dentz' death sentence was commuted to life imprisonment by General de Gaulle and two months later he died of a heart attack. N. Y. Times, Oct. 18, 1945; The Times (London), Dec. 14, 1945, p. 5, col. 3.

113. Among the Vichy ministers convicted of treason was Raphael Alibert, Minister 
Court of Justice has limited in part the broad implications of these earlier decisions. Factors which have included their length of service as Minister, the degree of their responsibility for the adoption of the policies which they executed, the manner in which they administered these policies, and finally their role, if any, in the Resistance have been considered by the court in mitigation of the punishment for the crime. ${ }^{114}$

One of the major groups of defendants indicted for treason before the specially created courts of justice involved those Frenchmen who through their writings or broadcasts had exhibited either pro-German or anti-Allied sympathies or who had supported the internal policies of Vichy. The charges brought against these persons were either intelligence with the enemy or demoralization of the nation.

The first of these trials involved the defendant, Georges Suarez, ${ }^{115}$ charged with intelligence with the enemy for his pro-Nazi pro-Vichy editorial policy in the news weeklies Aujourd'hui and Paris Soir. Suarez had been appointed editor of Aujourd'hui by Otto Abetz, German ambassador to Vichy, at a monthly salary of $\$ 1600$. The court, rejecting Suarez's claim that his editorial policies were not pro-German but merely supported law and order and that throughout the occupation he had acted in good faith though perhaps mistakenly, found him guilty of intelligence with the enemy and sentenced him to death. ${ }^{110}$

The basis for the conviction of Suarez was considerably broadened in subsequent trials. Similar convictions were secured against the editors of the Paris weekly, $J_{e}$ Suis Partout, ${ }^{117}$ an independent paper whose personnel were of Justice, who was charged with framing Vichy's fascist constitution and anti-sernitic laws and with imposing death sentences upon leading De Gaullists, N. Y. Times, March 8, 1947, p. 5, col. 1; Fernand de Brinon, French diplomatic representative in Germany; who admitted favoring a rapprochement with Germany, and was sentenced to death although the court conceded that he had rendered valuable services to the Resistance by obtaining the release of Frenchmen arrested by the Germans. N. Y. Times, March 7, 1947, p. 7, col. 3; Rene Bonnefoy, Minister of Information, charged with having given instructions to the press pursuant to Laval's orders which were systematically hostile to the Allies and to the Resistance movement. A. F. P., Paris, July 18, 1946; and Hubert Lagardelle, Minister of Labor, condemned for his enthusiastic support and exceution of the Vichy labor policies which resulted in the deportation of French workers to Germany. Le Mronde (Paris), July 16, 19, 1945.

114. Pierre Etienne Flandin, Vichy Foreign Minister for 56 days, was acquitted of treason and received a suspended sentence of five years national indignity. Ie Rfonde (Paris), July 23 and 28/29, 1946; Jean Bertholet, Mfinister of Communications, received a two year prison term and ten years national indignity. Le Mfonde (Paris), July 11, 12,1946 . The importance of these factors was also brought out in the trial of Lagardelle, $L_{e}$ Monde (Paris), July 16, 19, 1945.

115. Indictment summarized in Le Figaro (Paris), Oct. 22/23, 1944, p. 1.

116. Le Figaro (Paris), Oct. 24, 1944, pp. 1-2.

117. In November, 1946, six editor-owners of this paper vere placed on trial. Three were tried in absentia. The proceedings of the trial are summarized by Le Monde (Paris), Nov. 16, 17, and 26, 1946. 
not in the employ of Germany and whose editorial policies during the occupation had continued along the same ideological lines which had caused it to advocate pacifism and authoritarian government prior to the defeat of France. The defendants maintained that many of the allegedly traitorous articles were mere news dissemination and reflected no personal opinions, that others were written under duress and finally, that their support of a strong government in France was motivated solely by their belief in law and order. The court, however, rejected these defenses and found the defendants guilty of treason. ${ }^{118}$

Subsequent trials which have involved editors, ${ }^{110}$ free lance contributors, ${ }^{120}$ authors, ${ }^{121}$ cartoonists, ${ }^{122}$ radio script writers and broadcasters ${ }^{123}$ indicate clearly the futility of defenses based upon absence of intent to injure France, upon the right of free speech, ${ }^{124}$ lack of personal gain, ${ }^{125}$ or upon prior politi-

118. Two were condemned to death. One received life imprisonment. Le Monde (Paris), Nov. 26, 1946, p. 6.

119. Rene Benedetti, former chief editor of Marcel Deat's paper, L'Oeuvre (Paris), sentenced to life imprisonment. L'Oeuvre was conspicuously anti-Russian and pro FrancoGerman alliance, advocating in addition the defense of the French empire against attacks of the Allies. Reuters, Paris, March 2, 1943 (OWI, Eunopean NEws Drgest). Sec also trial of Lucien Combelle, owner of weekly newspaper, National Review, N. Y. Times, Dec. 24, 1944; of Robert Perrier, managing editor of L'Auto and Aujoutr'hui, N. Y. Herald Tribune, April 17, 1945, p. 3, col. 5.

120. See trials of Robert de Beauplan, editorial writer for Illustration and Le Malin, and formerly a university professor, Le Monde (Paris), Nov. 27, 1945, p. 4; and of Guy Crouzet, editorial writer for Noutvean Temps, Le Monde (Paris), Jan. 18, 1947, p. 8.

121. This group included Charles Maurras, noted French royalist, Abel Hermant, a member of the French Academy, Henri Beraud, noted anti-British author, and Robert Brassilach, French novelist and historian. Maurras and Hermant received life imprisonment, while the latter two were sentenced to death.

122. Raphael Souphault, cartoonist for L'Action Francaise and Je Suis Partout, was sentenced to fifteen years penal servitude for his criticism of de Gatulle and his ridictile of the members of the resistance. A.F.P., Paris, Jan. 30, 31, 1947.

123. The trials of these persons reveal a wide discrepancy in sentences. Paul Ferdonnet, who had emigrated to Germany in 1927 and who maintained that he mercly translated newscasts without broadcasting himself, was sentenced to death. N. Y. Herald Tribune, July 12,1945 , p. 3, col. 8. Francois de Vibraye, announcer for the Paris radio at a monthly salary of $\$ 144$ (paid by the German Embassy) received a ten ycar prison sentence. N. Y. Herald Tribune, Nov. 8, 1944, p. 14, col. 4. Jean-Herold Paquis, radio announcer who admitted his allegiance to the Germans, was sentenced to death. N. Y. Times, Sept. 18, 1945, p. 9, col. 6. Andre Algerron, director of the German controlled radio station, Radio Patrie, was condemned to death for operating the station as an auxiliary of the enemy propaganda service and for insulting members of the Resistance. A.F.P., Paris, Nov. 27, 1946.

124. This defense was expressly raised by Henri Beraud, but the court maintained that Beraud was being tried for his propaganda and not for his opinions and therefore held the defense inapplicable. N. Y. Herald Tribune, Dec. 30, 1944, p. 3, col. 1.

125. Le Monde (Paris), Nov. 16, 17, and 26, 1946. Similarly the defense offered by Abel Hermant that he was compelled to write allegedly propagandist material in order 
cal convictions long antedating the defeat of France. ${ }^{120}$ In general it has been sufficient to sustain convictions if evidence existed of anti-Allied sentiments or support for Vichy policies.

The other major category of defendants tried for treason by the special courts of justice included those persons who had, in one capacity or another, either public or private, taken part in the denunciations of patriots to the Gestapo or to the Vichy government, who had committed acts of violence towards these persons, who were responsible for their arrest, or who had engaged in other acts resulting in deportation of these persons to Germany. ${ }^{127}$ These defendants were primarily police officials, ${ }^{129}$ members of the Xrilitia, ${ }^{129}$ agents of the Gestapo ${ }^{130}$ and other civil servants of the Vichy government. ${ }^{131}$

to eat was not considered apparently as a sufficient defense to warrant acquittal or reduction of sentence. A.F.P., Paris, Dec, 15, 1945.

126. This defense was raised by Charles Afaurras who was well lsnown since World War I for his advocacy of authoritarian government. At his trial he maintained that he had always been true to his political beliefs and that he had not capitalized financially on his writings. N. Y. Times, Jan. 28, 1945, p. 13, col. 5; see note 122 supra.

127. Although the names of 64 economic collaborators were sent by the Minister of National Economy to the Minister of Justice for investigation, few of these vere even brought to trial. The report of the Minister of National Economy is summarized in Le Figaro (Paris), Oct. 4, 1944, p. 2; the only trials reported involved Andrew Marquer, textile manufacturer who received 20 years penal servitude for trafficling with the enemy, N. Y. Times, Oct. 19, 1945, p. 3, col. 4; id. Oct. 20, 1945, p. 4, col. 6; and MI. Berliet, head of the Berliet Automobile Works who received a two year imprisonment sentence for having put his factories to work for Germany and having assisted in the drive to obtain workers for Germany. N. Y. Times, June 9, 1946, p. 29, col. 2 The investigation of Louis Renault on similar charges before the evamining magistrate was reported in Le Figaro (Paris), Sept. 24/25, 1944, p. 2, but no indication of further proceedings has been found in the French Press.

Very few members of the legal profession were brought to trial although it was asserted in the Provisional Consultative Assembly that many of these persons had teen involved in collaborationist activities. Jourral OfFIcres, Débats, No. 69, p. 1705 (Aug. 2, 1945).

128. This group included former Prefect of Police, Amadee Bussiere, who was condemned to penal servitude for life for similar acts. Le Monde (Paris), April 11, 1945, p. 3. It Jean Giot, Vichy policeman who had fought with the French Liberation Army under Leclerc, was sentenced to death for having assisted in the execution or deportation of French resistance workers in pre-liberation days. N. Y. Herald Tribune, Dec. 29, 1945, p. 9 , col. 3 .

129. The trial and conviction of Joseph Darnaud, head of the militia, on charges of intelligence with the enemy was the outstanding case in this group. Darnaud's chief defense was that as a member of the armed forces, it was his duty to obey the orders of Petain, his chief. This defense was rejected by the court and Darnaud sentenced to death. Le Monde (Paris), Oct. 5, 1945, p. 2.

130. There were numerous reported trials of individuals who, as Gestapo agents, had denounced patriots and engaged in similar activities. Perhaps the most important trial involved 24 persons who were known as the "Brigade of Angels". Of these, nine vere sentenced to death and fifteen received varying terms of imprisonment. Le Alonde (Paris), Dec. 8/9, 1946, p. 8 .

131. One of the first acts of Petain was to order the dissolution of the secret socicties, 
Proof that the arrest or denunciation was actually committed by the defendant personally or by one of his subordinates ${ }^{132}$ was sufficient to secure conviction irrespective of whether he acted pursuant to orders.

The conduct of the collaboration trials has been sharply attacled by both the Right and Left in France. ${ }^{133}$ Rightist critics charged the courts with partiality, with violating the rights of the defendants, and with the imposition of disproportionately heavy sentences. ${ }^{134}$ Government attempts to remedy these defects in the purge machinery, ${ }^{135}$ however, were opposed by Leftist groups who regarded the trials as too slow and ineffective, the verdicts as too lenient, and the government use of its right of pardon as an unwarranted interference in the administration of justice. ${ }^{130}$ While many factors undoubtedly motivated these criticisms, it would appear that the conduct of the trials by the quasi-political courts has contributed in part to the general dissatisfaction and has failed to engender a spirit of popular confidence in its decisions.

notably the Freemasons. A Service of Research was created to carry out this program under the direction of Bernard Fay, former professor of the Collège de France. Fay, together with five associates was put on trial on charges of intelligence with the enemy for his activities in connection with this service which was alleged to have been responsible for the denunciation of some 6,000 Freemasons, the deportation of 989 and the execution of 549. Fay defended on the ground that his duty was merely to classify and publish documents relating to Freemasons and that it was purely intellectual rather than political. The defendants, however, were found guilty and received varying prison terms from penal servitude for life to five years. Le Monde (Paris), Nov. 28, 1946; id., Dec. 7, 1946, p. 4; see also A.F.P., Paris, Nov. 25, 1946.

132. This doctrine of "negative responsibility" was successfully invoked by the United States in its prosecution of the Japanese war criminals in the Philippines, N. Y. Times, May 5, 1947, p. 13, col. 3.

-133. Although originally in the minority those who advocated restraint and objected to the punishment of those who had acted in good faith or from a sense of misguided patriotism gradually came to speak for the majority. See Supptearent aU JourNar. Officier, Debats, No. 6, pp. 1-12 (Jan. 15, 1944), and No. 23, pp. 5-7 (March 16, 1944); also Journal Officier, Debats, No. 13, pp. 218-21 (Dec. 14, 1945). See also newspaper account of the Laval trial which aroused criticism from almost every clement in the French population; see note 92 sipra.

134. Garcon, Some Aspects of the Problem of the Purge in France, French Press and Information Service, Sèr. III, No. 184 E, Dec. 21, 1944; and Leroux, Problems of the Purge, FreE France, VII, No. 5, p. 251 (March 1, 1945).

135. See notes 91-3 supra. Official Swiss protests against the summary conviction of Swiss citizens on charges of collaboration without proof and without legal cause were acknowledged by the French government and admitted to be well founded. The French government appointed a special official in the Ministry of Justice to study the problem but according to Swiss reports, the problem is still unsettled. Journal de Gendve (Geneva), Feb. 25, 1947, No. 47.

- 136. Farmer, France before the Problem of Political Jistice, in ExTINFor, PAGES DE FRANCE, No. 7413 (Sept., 1946). 
Perhaps the chief significance of the French trials lies in the concept of treason which was developed by the courts-a concept which does not necessitate a showing of specific intent to assist the enemy but merely requires proof of the commission of acts which result in aid to the enemy or are considered contrary to the national interest. While such a concept was not unknown to French law and in fact does serve to protect the security of the state, it would seem to ignore the historic safeguards written into the law of treason to protect citizens from political oppression or popular passion. In this respect it appears to run contrary to the spirit of the French penal code provisions. ${ }^{23 \pi}$

\section{Conclusion}

In the postwar period Anglo-American and European countries were faced with the problem of implementing an immediate policy goal-satisfying the demands of an outraged population for punishment of persons regarded as criminals-without doing violence to traditional legal doctrine. The relative values placed on these conflicting legal and political policy goals substantially accounts for the varying treatment accorded collaborators in the different European communities.

The modification of trial procedures and the substantive changes in the treason laws to cover propaganda activities which were instituted in Great Britain and Switzerland do not appear to have caused serious difficulties with respect to the actual trials nor to have evoked popular criticism. In France, on the other hand, the exigencies of the situation demanded more drastic modifications both in the customary trial procedures and in the traditional doctrines of intent and non-retroactive legislation. Although France attempted to avoid an infringement of the principle of non-retrosctivity through the use of "interpretive" provisions, it is clear that the French trials proceeded on a theory of criminality which was in fact retroactive in nature regardless of the name attached to it.

. While the theory of retroactive justice is normally abhorrent to civilized countries, strict adherence to the doctrine of non-retroactivity vould have seriously impeded effective action against many of the defendants in the collaborationist trials. The trials, therefore, cannot be evaluated solely in terms of the justice or injustice of the result to the defendants. Nor can criticism of the establishment" of quasi-political courts, the issuance of "interpretive" provisions, the relaxation of intent requirements, or the outlawing of particular defenses be rested solely upon the framework of legal precedent. To do so would be to ignore the bitterness which survived hostilities and the exigencies of a highly charged political situation.

137. These provisions had sought to protect the citizens from political oppression by delimiting the crime of treason into specific acts engaged in for specific purposes; protsction by this means would not seem to be possible under the new concept in view of the difficulties of defining the crime in precise terms before its commission, and of the susceptibility of the criterion of national interest to differing judgments in different periods of time. 